(衛 ${ }_{\text {EISEI }}^{\text {生 }}$ KAGAKU

高速液体クロマトグラフィーによる柑橘類中 o-Phenylphenol (OPP) の定量

林 時司, 土屋博紀, 安達俊子,

大森裕子, 河合 聰, 大野武男

岥阜薬科大学 ${ }^{11}$

\title{
High-Speed Liquid Chromatographic Determination of o-Phenylphenol (OPP) in Citrus Fruits
}

\author{
TOKIshi Hayashi, Hironori Tsuchiya, Toshiko AdachI, \\ Yuko Ohmori, Satoshi Kawai and Takeo Ohno \\ Gifu College of Pharmacy ${ }^{1)}$
}

(Received October 3, 1978)

\begin{abstract}
A method for high-speed liquid chromatographic determination of 0 -phenylphenol in citrus fruits was investigated. Determination was carried out successfully by using $p$-tert-amylphenol as an internal standard. $o$-Phenylphenol and the internal standard were steam-distilled from citrus fruit samples, and extracted with ether from the resulting distillate after washing with carbon tetrachloride. The recovery of 0 -phenylphenol was $93.8 \%$ ( $\sigma$ rel. $1.5 \%$ ).
\end{abstract}

Keywords_- high-speed liquid chromatography ; gradient elution; $o$-phenylphenol ; citrus fruits ; steam distillation

緒言

o-Phenylphenol (OPP) は柑橋類の白徽病, 緑徽病, ビくぐされ病，たん瘨病等に效力があり，防徽剂として その効果の著しいことが認められているが，毒性が強く 安全性に問題があるとされている。

OPP の定量法には，ペーパークロマトグラフィー， 薄層クロマトグラフィー等で分離した後, 発色試薬と反 応させて比绝定量する方法 ${ }^{2-4)}$ の他，ガスクロマトグラ フィー, ${ }^{5-8)}$ ケイ光法 ${ }^{9,10)}$ 等が報告されている. しかし， 精度, 選択性, 操作の簡便性等の点で改良の余地がある と思われる。

そこで, 著者らは, 高速液体クロマトグラフィーを利
用する柑橘類中の OPP の迅速, から, 信頼性の高い分 析法を確立ずべく検討を加えたので報告する。

\section{実 験 方 法}

1. 試薬 o-Phenylphenol, p-tert-amylphenol, p-sec-butylphenol, p-tert-butylphenol, 2,6-di-tertbutylphenol 扮よび $\beta$-naphthol は東京化成工業社製の ものを用いた。皇の他の試薬は市肘の試薬特級品を用い た，有機溶媒はいずれも蒸留精䧶したものを使った。

2. 高速液体 クロマトグラフ 協和精密 $\mathrm{KSD}-\mathrm{W}-$ 321 型ミニマイクロポンプ, 協和精密 KD-3 プランジャ 一ダンパー, 協和精密 $\mathrm{KMH}-6 \mathrm{~V}$ 超高圧切換バルブ，島 津-デュポン 840 型高速液体クロマトグラフ用 UV 検出

1) Location: Mitahora Higashi 5-Chome, Gifu (岐阜市三田洞東 5 丁目).

2) H. Thaler, H. Günder, Dtsch. Lebensmitt Rdsch., 56, 262 (1960).

3) M. Ihloff, M. Kalitski, Dtsch. Lebensmitt Rdsch., 56, 139 (1960).

4) V. Chioffi, Boll. Laboratori Chim. Prov., 16, 366 (1965).

5) R. Thomas, Analyst., 85, 551 (1960).

6) J. Vogel, J. Deschusses, Mitt. Lebensmitt. Hyg., 54, 330 (1963).

7) E. Pillion, J. Gas Chromatogr., 3, 238 (1965).

8) 外海泰秀, 佐野裕子, 伊藤誉志男, 㦄田雅洋, 食衛誌, 16, 397 (1975).

9) H. Böhme, G. Hofmann, Z. Lebensmitt. Untersuch., 114, 97 (1961).

10) H. Thiel, Dtsch. Lebensmitt Rdsch., 62, 309 (1966). 

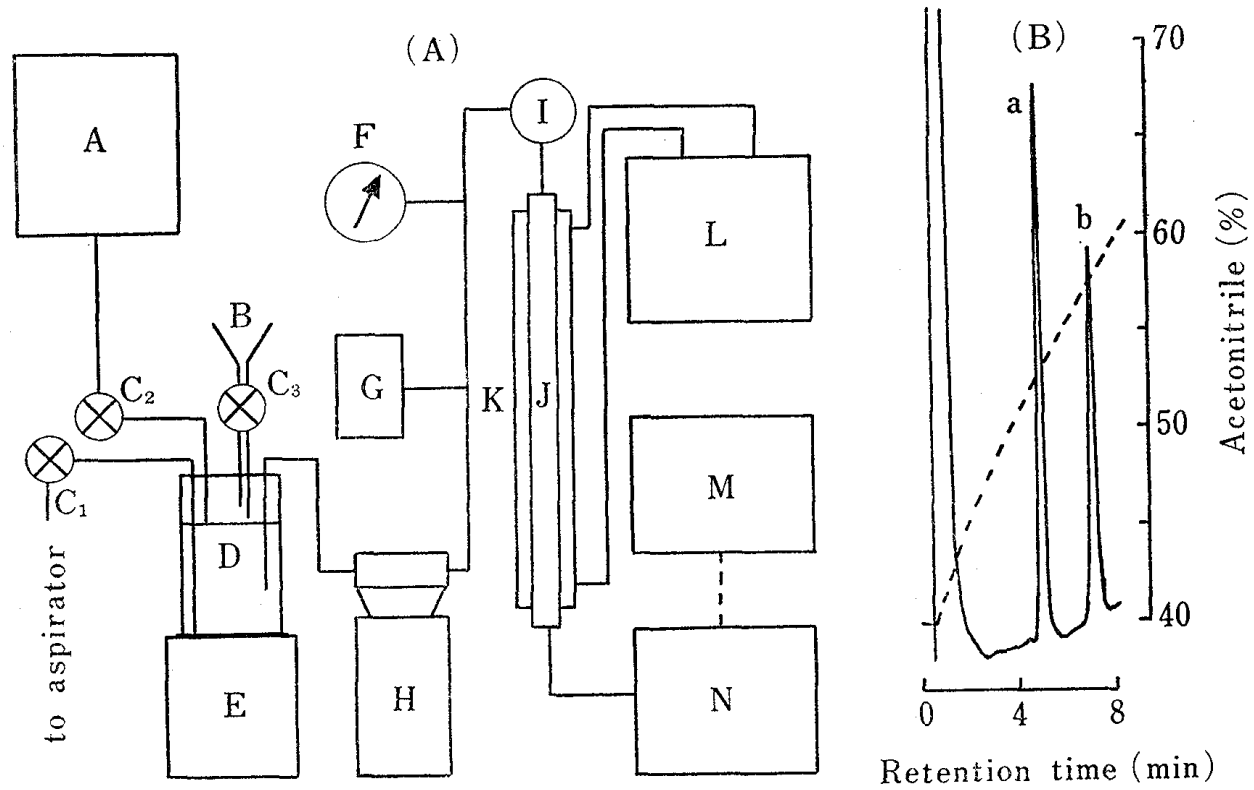

Fig. 1. Schematic Diagram of Gradient System and Gradient Elution of Standard Mixture of OPP and PTAP

A, reservoir (95\% acetonitrile); $\mathrm{B}$, funnel ; C, cock ; D, mixing vessel; E, magnetic stirrer; F, pressure gauge $\left(330-360 \mathrm{~kg} / \mathrm{cm}^{2}\right.$, flow-rate $\left.0.73 \mathrm{ml} / \mathrm{min}\right) ; \mathrm{G}$, damper; $\mathrm{H}$, pump ; $\mathrm{I}$, valve injector; $\mathrm{J}$, column $(2.1 \mathrm{~mm} \times 30 \mathrm{~cm}$, Lichrosorb $\mathrm{RP}-18(5 \mu \mathrm{m}))$; $\mathrm{K}$, column jacket; L, constant-temperature circulator $\left(50^{\circ}\right) ; \mathrm{M}$, recorder ; N, UV detector The gradient was prepared in the following manner.

1. About $25 \mathrm{ml}$ of $40 \%$ aqueous acetonitrile solution is placed in the mixing vessel (D) from the funnel (B).

2. Aqueous acetonitrile, $40 \%$ solution, is pumped through the column.

3. The sample solution is injected into the valve injector.

4. When $40 \%$ aqueous acetonitrile solution is decreased to $20 \mathrm{ml}$, the valve injector is opened. And the cock $\mathrm{C}_{3}$ is closed and the cock $\mathrm{C}_{2}$ is opened so as to connect the mixing vessel with reservoir in which $95 \%$ aqueous acetonitrile solution is placed.

5. When the separation comes to end, the pump is stopped.

6. The valve injector and the cock $\mathrm{C}_{2}$ are closed and the cocks $\mathrm{C}_{1}$ and $\mathrm{C}_{3}$ are opened. The mixing vessel is washed with $40 \%$ aqueous acetonitrile solution before next run. Peaks ; $a=$ OPP, $b=$ PTAP.

器 $(254 \mathrm{~nm}), \quad$ グラージエントミキサーおよび循環用恒 温槽等から Fig. 1 (A) に示すょらな装置を組不立て た.・1)操作法については図中に詳しく説明した。

\section{3. 高速液体クロマトグラフィー用カラム メルク} 社慗の Lichrosorb RP-18 (5 $\mu \mathrm{m})$, Lichrosorb RP-8 $(10 \mu \mathrm{m})$ を平衡スラリー法で，それぞれ $2.1 \mathrm{~mm} \times 30$ $\mathrm{cm}, 2.1 \mathrm{~mm} \times 50 \mathrm{~cm}$ のステンレスカラムに充てんし た。

\section{4. 定量法果皮はアルマイト製の扔らし金で扔ろ} した後, 適量の水を加光, ホモジナイズし, 果皮 $1 \mathrm{~g}$ に 相当するホモジネイトに水を加党て $20 \mathrm{ml}$ とする。ま た, 果汁の場会は,ガラス製のレモンしぼり器でしぼっ た後, ホモジナイズし, 果汁 $10 \mathrm{ml}$ に相当するホモジネ イトに水を加えて $20 \mathrm{ml}$ とする。こうして得られた試料
のホモジネート $20 \mathrm{ml}$ に内部標準物質 p-tert-amylphenol (PTAP) のメタノール溶液 $(200 \mu \mathrm{g} / 0.1 \mathrm{ml}) 0.1 \mathrm{ml}$ 之, りん酸 $1 \mathrm{ml}$ を加之て水蒸気蒸留する。 その留液 $50 \mathrm{ml}$ に $1 \mathrm{~N}$ 水酸化ナトリウム溶液 $10 \mathrm{ml}$ を加之, 四壏 化炭素 $10 \mathrm{ml}$ で洗浄した後, 有機層を除く. 水層に食壏 $20 \mathrm{~g}, 2 \mathrm{~N}$ 塩酸 $10 \mathrm{ml}$ を加え，エーテル $10 \mathrm{ml}$ で抽出す る. エーテル艄を無水硫酸ナトリウムで乾燥した後, 口 一タリーエバポレーターで溶媒を留去し, 残渣をジメチ ルホルムアミド (DMF) 3 滴と水 1 滴で溶かし, その約 $60 \mu \mathrm{l}$ を高速液体クロマトグラフに注入する.

㭘量線法， OPP 標準品 O-10 $\mu \mathrm{g}$ と内部標準物質 PTAP $200 \mu \mathrm{g}$ を含むメタノール溶液をエバポレートし， 残渣を $\mathrm{DMF} 3$ 滴と水 1 滴で溶かし, 高速液体クロマト グラフに注入し, 得られたクロマトグラム上のピーク高

11) T. Hayashi, T. Sugiura, S. Kawai, T. Ohno, J. Chromatogr., 145, 141 (1978). 
TABLE I. Retention Time of OPP and Phenols

\begin{tabular}{cc}
\hline Compound & Retention time (min) \\
\hline o-Phenylphenol & 5.0 \\
p-tert-Amylphenol & 7.0 \\
$p$-sec-Butylphenol & 6.0 \\
$p$-tert-Butylphenol & 5.4 \\
2, 6-Di-tert-butylphenol & 20.4 \\
$\beta$-Naphthol & 3.0 \\
\hline
\end{tabular}

For high-speed liquid chromatographic conditions, see legend to Fig. 1 .

さ比をプロットし作成する.

\section{結果と考察}

\section{1. 分離条件および内部標準物質の検討}

OPP の分離には，移動相液体の経済性を考慮し，逆 相分配系を利用した。また一般に, 単一成分の分離定量 には一定組成の移動相を利用することが多いが，グラー ジェント溶離を行うと，1）テーリングが抑兄られピー クが鋭くなるため，ピーク高さ比による定量に都合がよ い，2）注入試料容量を增すことがでさる．3）内部標 準物質の選択が容易汅なる。等が期待できる、そこで固 定相には Lichrosorb RP-18 $(5 \mu \mathrm{m})$ を用い，水一アセ卜 ニトりル混合溶媒によるグラージエント溶離法を採用し た。

Table I には OPP の分析に使用した分離条件に拉け る OPP 却よび若干のフェノール類の retention time を示した。この結果から，OPP と分離が完全であり， retention time の差が比較的短い PTAP 预よび $\beta$ naphthol が内部標準物質として適当であると考兄られ る、しかし，実際の試料を分析すると $\beta$-naphthol の retention time の近くに妨害ピークが現れるため, 内部 標準物質としてはPTAP 用いることにした. Fig. 1 (B) に標準品の OPP および内部標準物質 PTAP の分 離例を示す。点線は移動相中のアセトニトリルの濃度変 化を表わす。

\section{2. 抽出溶媒の检討}

水溶液からの OPPおよび PTAP の有機溶媒化よる抽 出性について調べるため, エーテル，nーへキサン，四塩 化炭素等の有機溶媒化ついて検討を加兄た。その結果， エーテルを用いた場合，最も良好な結果が得られ，10 $\mathrm{ml}$ を用いた場合，両物質とも $50 \mathrm{ml}$ の水層から 1 回の 抽出操作で，注淁完全化抽出できることがわかった。な 招，定量に際して蛙，水層とエーテル層の分離をよくす る目的で，食塩を水層に飽和させた。

\section{3. 前処理法の検討}

レモン, グレープフルーツの果皮, 果汁のホモジネイ

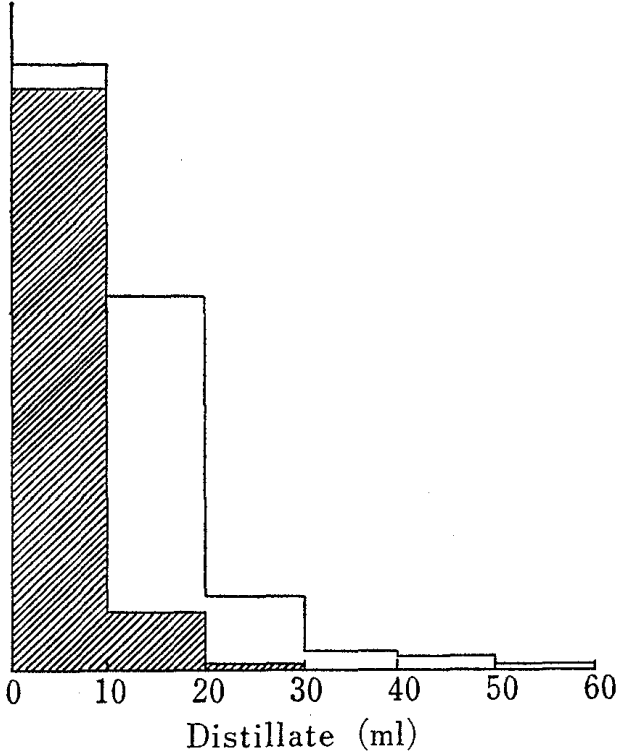

Fig. 2. Steam Distillation of OPP and PTAP : OPP, WTIA : PTAP.

トをエーテル抽出して, 高速液体クロマトグラフにかけ たところ, OPP のピークの直後に 分離不完全な妨害ピ 一クが観察された．この妨害ピークは，水層の液性を調 節し，溶媒で洗浄するといった簡単な操作では除去でき なかった。そこで, 水蒸気蒸留を試久た。 OPP および PTAP の水溶液 $20 \mathrm{ml}$ にりん酸 $1 \mathrm{ml}$ を加え, 水蒸気蒸 留したときの OPP 拈よび PTAP の留出パターンを Fig. 2 に示す. OPP, PTAP 共に, 最初の留液 $50 \mathrm{ml}$ 中に注淁完全に留出することがわかったので，定量法に 伺いて $50 \mathrm{ml}$ 採ることにした。 また，レモン，グレープ フルーツの果皮, 果汁にこの操作を加兄, 留液に $1 \mathrm{~N}$ 水 酸化ナトリウム溶液を加えてアルカリ性とし, 四塩化炭 素で洗浄し精油成分を除去した後， $2 \mathrm{~N}$ 塩酸を加兄液性 を酸性としェーテル抽出した場合には，Fig.3 からも 明らかなよらに，直接抽出法の場合に認められた OPP のピークの直後に現れた分離不完全な妨害ピークは観察 できなかったささらに，水蒸気蒸留を行うことによっ て, 抽出時の水層と有機層との分離も改善された。

\section{4. 柑橘類中の OPP の定量}

果物店, スーパーマーケット等で購入したレモン，グ レープフルーツの果皮拈よび果汁中の OPP の定量に本 定量法を応用した。

Table II は, レモン果汁 $20 \mathrm{~g}$ に OPP $10 \mu \mathrm{g}$ を添加し て，回収率および精度を調べた結果である．内部標準物 質に対する OPP の平均回収率は $93.8 \%$ ，相対標準偏差 $1.5 \%$ と良好な結果が得られた。また，レモン果皮，グ レープフルーツ果皮扣よび果汁についても，注涪同様の 
TABLE II. Recovery of OPP from Lemon Juice

\begin{tabular}{ccc}
\hline $\begin{array}{c}\text { Amount added } \\
(\mu \mathrm{g})\end{array}$ & $\begin{array}{c}\text { Amount found } \\
(\mu \mathrm{g})\end{array}$ & $\begin{array}{c}\text { Recovery } \\
(\%)\end{array}$ \\
\hline 10.00 & 9.50 & 95.0 \\
10.00 & 9.40 & 94.0 \\
10.00 & 9.30 & 93.0 \\
10.00 & 9.30 & 93.0 \\
10.00 & 9.20 & 92.0 \\
10.00 & 9.40 & 94.0 \\
10.00 & 9.60 & 96.0 \\
10.00 & 9.30 & 93.0 \\
\hline
\end{tabular}

The recovery test was carried out after addition of $10 \mu \mathrm{g}$ of OPP to $20 \mathrm{~g}$ of lemon juice.

$\mathrm{T}_{\mathrm{ABLE}}$ III. Amount of OPP in the Peel and Juice of Lemon

\begin{tabular}{crl}
\hline \hline Sample No. & \multicolumn{2}{c}{ OPP (ppm) } \\
\hline 1 & 8.13 & 0.06 \\
2 & 8.33 & 0.10 \\
3 & 9.33 & 0.07 \\
4 & 7.53 & 0.05 \\
5 & 5.93 & 0 \\
6 & 16.66 & 0.14 \\
7 & 2.67 & 0 \\
8 & 1.13 & 0 \\
9 & 10.79 & 0.03 \\
10 & 13.33 & 0.24 \\
11 & 7.73 & 0.06 \\
12 & 2.67 & 0 \\
13 & 13.26 & 0.03 \\
14 & 11.33 & 0.05 \\
15 & 7.60 & 0.07 \\
\hline
\end{tabular}

結果が得られた。

Table III はレモンについて得られた分析結果である. また，Fig. 3 にはその際得られたクロマトグラムを示 した.

\section{OPP の同定}

標準品の OPP と同じ retention time を有する柑樀類 由来の物質が OPP であることを確かめる目的で，ジア ゾメタンによるメチル化反応を利用した，OPP はフェ ニル基による立体障害のため,ジアゾメタンによる完全 メチル化は困難であるが，メチル化率が一定であれば， 生成物 のretention time とともに, 残存フェノール体と メチル体との生成比が情報として得られ，同定の目的に

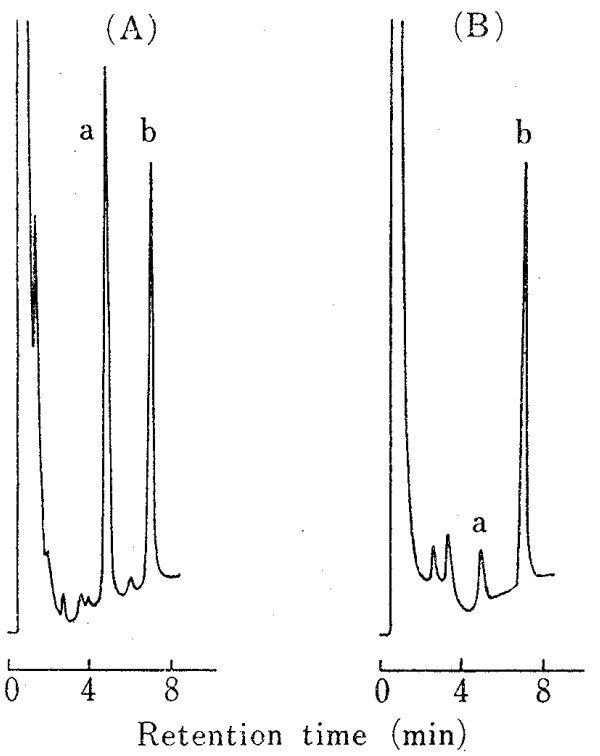

Fig. 3. Chromatograms Obtained from Lemon Peel (A) and Juice (B) by the Overall Procedure

For operating conditions, see legend to Fig. 1. Peaks $; a=$ OPP,$b=$ PTAP.

は有利と考えられる、そこで，ジアゾィタンを用いるメ チル化率, 液ク口条件, 内部標準物質等について検討し た.

最初に，標準品の OPP $20 \mu \mathrm{g}$ に dibenzyl (DB) $400 \mu \mathrm{g}$ を含むメタノール0.4 mi を加えて溶かし，その約 $60 \mu 1$ を高速液体クロマトグラフに注入した。また，その0.2 $\mathrm{ml}$ に常法 ${ }^{12)}$ によって得たジアゾメタンのエーテル溶液 $2 \mathrm{ml}$ を加えて一夜室温で放置した。乞の後, 過剩のジ アゾメタンを溶媒を留去し, 残渣をDMF 3 㵜と水 1 滴 に溶かし，高速液体クロマトグラフに注入した。Fig.4 はその際得られた OPPとDBのメタノール溶液および それをジアゾメタンで処理した溶液について得られたク ロマトグラムである。な执，この際には，Lichrosorb RP-8を充てんしたカラムを用いている。ジアゾメタン 処理後得られたクロマトグラムに执いて，ピークbは OPP をジメチル硫酸でメチル化することによって別途 合成した 0 -methoxybiphenyl (OMB) のそれと一致し， ピーク a は未反応の OPP, ピーク c は内部標準物質とし て用いたDBに対応している。また，Table IVはピー ク a のピーク c V対する高さ比, ジアゾメタン処理後の ピーク bのピーク c に対する高さ比抢よび両ピーク高さ 此の比をまとめたものであるＯOPP のジアゾメタンに よるメチル化反応は再現性よく行われていることがわか

12）上尾庄次郎, 佐々木喜男, 堀井善一, “実験化学講座 18巻, 有機化合物の反応 II (下), ”第 2 版, 日本化学 会編，丸善，東京， $1964 ， p .528$. 
TABLE IV. Methylation of OPP with Diazomethane

\begin{tabular}{cccc}
\hline Sample & $\begin{array}{c}\text { Before methylation }(B) \\
\text { Peak height ratio }(a / c)\end{array}$ & $\begin{array}{l}\text { After methylation }(A) \\
\text { Peak height ratio }(b / c)\end{array}$ & $(A) /(B)$ \\
\hline OPP & 1.71 & 0.99 & 0.58 \\
& & 0.95 & 0.56 \\
& & 0.98 & 0.57 \\
Substance derived & 1.16 & 0.99 & 0.58 \\
from lemon peel & & 0.96 & 0.56 \\
\hline
\end{tabular}

The mixture of OPP and DB was separated before and after treatment with diazomethane (see Fig. 4). And the mixture of $\mathrm{DB}$ and the substance derived from lemon peel, which gave the same retention time as that of OPP, was also treated in the same manner.

Peaks : $a=$ OPP, $b=$ OMB, $c=D B$.

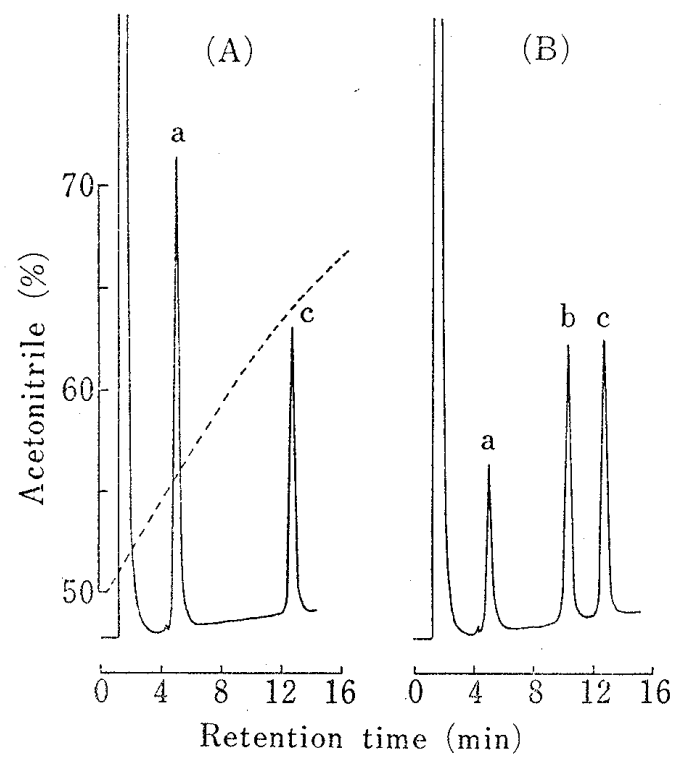

Fig. 4. Chromatograms obtained from Standard Mixture of OPP and DB Treated (B) and Untreated (A) with Diazomethane

Operating conditions: column, $50 \mathrm{~cm}$ (ID, $2.1 \mathrm{~mm}$ ) Lichrosorb RP-8 $(5 \mu \mathrm{m})$; column temperature, $50^{\circ}$; mobile phase, initial $50 \%$ acetonitrile, the gradient was prepared by adding $90 \%$ acetonitrile into mixing vessel $(20 \mathrm{ml})$; flow rate, $0.7 \mathrm{ml} / \mathrm{min}$; detector, UV photometer $(254 \mathrm{~nm})$.

Peaks ; $\mathrm{a}=\mathrm{OPP}, \mathrm{b}=\mathrm{OMB}, \mathrm{c}=\mathrm{DB}$.

る.次に, レモン果皮を分析した際, OPP の retention time に相当するフラクションを繰り返し分取し（OPP
$15 \mu \mathrm{g}$ 程度に相当する量), これと水を加えて $10 \mathrm{ml}$ とし， 食塩を飽和した後エーテル $10 \mathrm{ml}$ で抽出し，エーテル層 をエバポレートした． 残督を内部標準物質として DB $400 \mu \mathrm{g}$ を含むメタノール0.4 $\mathrm{ml}$ に溶加し，以下，標品 の場合と同様の操作を行った，その結果，レモン果皮由 来の物質は，Lichrosorb RP-8を充てんしたカラムを用 いてむ retention time は標準品のそれと一致し，ジア ゾメタン処理した場合も，標準品の時と同様，末反応物 質とともに OMB と同じ retention time 飞反応生成物 のピークが観察された。 李た, Table IVからメチル化 反応の収率も標準品の場合とよく一致していることがわ かる。

以上のように，二種類のカラムを用いた場合の retention time, ならびにジアゾィタンによるメチル化反応に 対する挙動が標準品のそれらとよく一致しており，本分 析法によって，相樀類中に含まれている OPP が特異的 に定量されていると結論できる。

\section{結論}

高速液体クロマトグラフィーに上る柑樀類中の OPP の定量法について検討を加光た，との結果，水蒸気蒸 留, 抽出等の前処理操作上で OPP と同様の挙動をする PTAP を内部標準物質として利用したため，操作が簡 便で精度の高い分析法を設定できた。また，高速液体ク ロマトグラフィーの分離時間も10分以内と短く, 充分実 用性のある方法と考えている。 